\title{
Influence of amprolium and toltrazuril on the disposition kinetics of levofloxacin in broiler chickens
}

\author{
El-Banna, H. A. ${ }^{1}$, El- Hewaity, M.H. ${ }^{2}$ and Amera Abd El Latif ${ }^{2}$ \\ 1- Department of Pharmacology, Faculty of Veterinary Medicine, Cairo University \\ 2- Department of Pharmacology, Faculty of Veterinary Medicine, El-Sadat City \\ University
}

\begin{abstract}
The pharmacokinetic properties of levofloxacin alone and with amprolium or toltrazuril were determined in broiler chickens after a single IV and oral administrations. After IV injection, levofloxacin serum concentration was best to be described by a two-compartment open model. Amprolium resulted in a significance increase in $\mathrm{Vd}_{\mathrm{ss}}$ and $\mathrm{Cl}_{\text {tot }}(3.05 \pm 0.17$ and $0.65 \pm 0.023 \mathrm{~L} / \mathrm{kg}$, respectively). In contrast, toltrazuril induced a significance decrease in $\mathrm{Vd}_{\mathrm{ss}}$ and $\mathrm{Cl}_{\text {tot }}(1.71 \pm 0.17$ and $0.32 \pm 0.015 \mathrm{~L} / \mathrm{kg}$, respectively) compared with levofloxacin alone $(2.36 \pm 0.34$ and $0.44 \pm 0.009 \mathrm{~L} / \mathrm{kg}$, respectively). The elimination half-life and the mean residence time of levofloxacin were $4.07 \pm 0.24$ and $5.40 \pm 0.26,3.89 \pm 0.24$ and $4.77 \pm 0.28,4.10 \pm$ 0.45 and $5.38 \pm 0.36 \mathrm{~h}$. in control, amprolium and toltrazuril respectively. Following oral dosing the maximum serum concentration was $3.27 \pm 0.13,2.17 \pm 0.097$ and 2.95 $\pm 0.11 \mu \mathrm{g} / \mathrm{ml}$ reached at $1.32 \pm 0.096,0.92 \pm 0.057$ and $1.30 \pm 0.037 \mathrm{~h}$ in control, amprolium and toltrazuril respectively. Amprolium and toltrazuril resulted in a significance decrease in interval between doses $(19.10 \pm 0.58$ and $19.29 \pm 0.51 \mathrm{~h}$ respectively), compared with levofloxacin alone $(27.39 \pm 1.80 \mathrm{~h}$.). Oral bioavailability was found to be $107.47 \pm 9.23,75.74 \pm 4.50$ and $53.51 \pm 2.45 \%$ in control, amprolium and toltrazuril respectively. It was concluded that the pretreatment of (amprolium and toltrazuril) with levofloxacin altered the pharmacokinetic profile of levofloxacin.
\end{abstract}

Keywords: amprolium - toltrazuril - levofloxacin - broiler chickens

\section{INTRODUCTION}

Pharmacokinetic drug interactions are of great clinical significance in veterinary practice. Drugs have the same metabolic pathway usually show drug interactions in its concomitant administration (Abdelsalam and Ford, 1986). These constitute a major problem facing the poultry production as many compounds over 13 have been usually added to poultry rations as feed additives (Jones and Ricke, 2003) which may interact with any administered therapeutic agent. From this view point, dosages of antimicrobials used in poultry farms must be adjusted to compensate for its interaction with these additives. Anticoccidials are one of these compounds; their programs have been substantially varied in its clinical application in poultry farms (Echman, 1997). Amprolium is a thiamine analogue used in treatment and prevention of coccidiosis in poultry and rabbits (McDougald and Reid, 1997). Toltrazuril, a triazinetrione derivative, is intended for use in chickens and turkeys for the prevention and treatment of coccidiosis (Vertommen et al., 1990) Levofloxacin is a third generation fluoroquinolone (Martinez et al., 2006). It possesses excellent activity against Gram-positive, Gram-negative and anaerobic bacteria (North et al., 1998). The 
aim of this study is to emphasize the effect of amprolium and toltrazuril on the disposition kinetic of levofloxacin in broiler chickens.

\section{MATERIAL AND METHODS}

\section{Drug:}

Levofloxacin was obtained as pure powder from Elpharonia for Medical Industries (pharopharma) Borg El-Arab City, Egypt.

Amprolium was obtained as water soluble powder $20 \%$ under trade name Amprolium 20\%) ${ }^{\circledR}$ from Adwia company.

Toltrazuril was obtained as oral solution $2.5 \%$ under trade name (Tolacox) ${ }^{\circledR}$ from Pharma-Swede Egypt company.

\section{Birds:}

Fifty four apparently healthy SASO broiler chickens of both sexes weighing from 1400-1800 $\mathrm{g}$ and 45-55 day old were used. The chickens were housed in hygienic floor system chambers and were fed on antimicrobial free ration to ensure that chicken bodies are free from any drug residues.

\section{Experimental design: \\ Single dose studies:}

Three main groups of 6 chickens each were used. Birds of the $1^{\text {st }}$ group were left as control group while those in the $2^{\text {nd }}$ and $3^{\text {rd }}$ groups were pretreated with amprolium (240 $\mathrm{ppm})$ for 5 consecutive days and toltrazuril ( $25 \mathrm{ppm})$ for 2 consecutive days, respectively. After the last dose by 2 hours (to ensure that amprolium and toltrazuril reach its maximum serum concentration), levofloxacin was injected i.v. in a single dose (10 mg/kg.b.wt.) in the left wing vein of each bird of these 3 main groups. Blood samples were collected from the right wing vein of each bird at 5,10, 20 and 30 minutes and 1, 2, $4,6,8,12$ and 24 hours after injection. Serum was stored at $-20^{\circ} \mathrm{C}$ until assayed. These chickens were kept for 15 days devoid of any antibiotic or anticoccidial drugs to ensure complete withdrawal of the administered drugs then, birds of the $1^{\text {st }}$ group were left as control group while those in the $2^{\text {nd }}$ and $3^{\text {rd }}$ groups were pretreated with amprolium (240 $\mathrm{ppm})$ for 5 consecutive days and toltrazuril ( $25 \mathrm{ppm})$ for 2 consecutive days, respectively. After the last dose by 2 hours each bird in all 3 groups was orally given a single dose of levofloxacin $10 \mathrm{mg} / \mathrm{kg}$ b.wt. Blood samples were collected from the right wing vein of each bird at 10, 20 and 30 minutes and 1,2, 4, 6, 8, 12 and 24 hours after dosing.

Multiple dose study to determine the tissue distribution and residual content:

Three main groups of 18 chickens each were used. Birds of the $1^{\text {st }}$ group were left as control group while those in the $2^{\text {nd }}$ and $3^{\text {rd }}$ groups were pretreated with amprolium (240 ppm) for 5 consecutive days and toltrazuril $(25 \mathrm{ppm})$ for 2 consecutive days, respectively. After the last dose by 2 hours (to ensure that amprolium and toltrazuril reach its maximum serum concentration), each bird in all 3 groups was given for three days levofloxacin orally at a dose rate of $10 \mathrm{mg} / \mathrm{kg}$ body weight. Three chickens were randomly selected from each group and slaughtered $2 \mathrm{~h}$ after the last dose of administration then at $1^{\text {st }}, 3^{\text {rd }}, 5^{\text {th }}, 7^{\text {th }}, 9^{\text {th }}$ day. Tissues samples (liver, kidney, lung, spleen, fat, breast muscle) were collected from all slaughtered birds. One gram of tissue sample (liver, kidney, lung, spleen, fat, and breast muscle) was added to $1 \mathrm{ml}$ of saline solution and thoroughly homogenized. Tissue sedimentation allowed for settling and the supernatant was transferred to sterilized tubes.

\section{Analytical Procedures:}

Concentrations of Levofloxacin in serum and tissue samples were determined by a modification of the agar-plate diffusion method (Arret et al., 1971) using 
Escherichia coli (ATCC 25922) as test organism. Protein binding of levofloxacin was estimated according to the method explained by Lorian (1975). The pharmacokinetic parameters were calculated according to Baggot (1978). All statistical analysis was carried out according to Snedecor and Cokran (1980).

\section{RESULTS}

The semilogarithmic serum concentration-time curves of levofloxacin in broilers, after a single intravenous injection of $10 \mathrm{mg} / \mathrm{kg}$ b.wt. alone, pretreated with amprolium and pretreated with toltrazuril are depicted in fig. (1). The corresponding kinetic parameters are described in Table (1). The semilogarithmic serum concentration-time curves of levofloxacin in broilers after a single oral administration of $10 \mathrm{mg} \cdot \mathrm{kg}^{-1}$ b.wt. alone pretreated with amprolium and pretreated with toltrazuril are depicted in Fig. (2). The corresponding kinetic parameters are described in Table (2). The mean serum and tissues concentrations of levofloxacin $(\mu \mathrm{g} / \mathrm{ml}$ or $\mu \mathrm{g} / \mathrm{gm})$ alone pretreated with amprolium and pretreated with toltrazuril in broiler chickens following oral administration of $10 \mathrm{mg} / \mathrm{kg}$ b.wt., once daily for 3 consecutive days are described in Tables $(3,4)$.

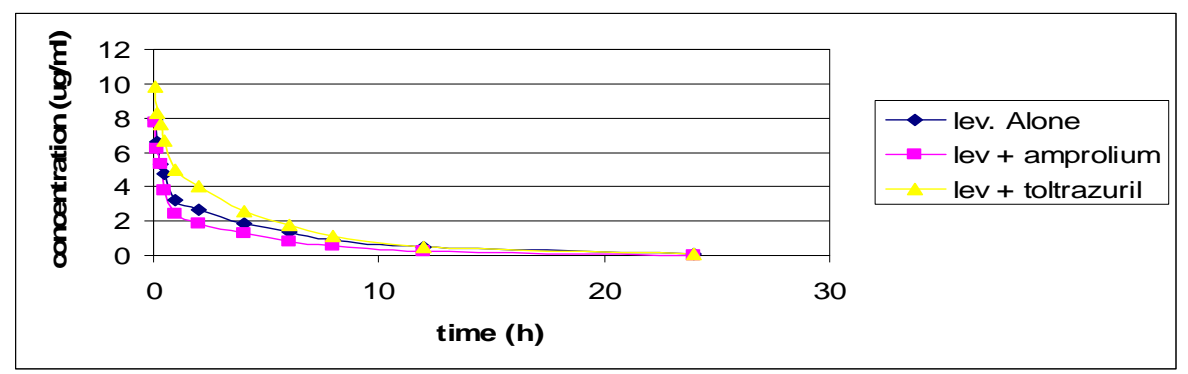

Fig. 1: Graph depicting the time course of levofloxacin in serum of broilers after a single intravenous injection of $10 \mathrm{mg} / \mathrm{kg} . b . w t$. alone, pretreated with amprolium and pretreated with toltrazuril.

Table 1: Mean pharmacokinetic parameters of levofloxacin in broilers after a single intravenous injection of $10 \mathrm{mg} / \mathrm{kg}$. b.wt. alone (Levo.I.V.) and /or pretreated with amprolium (Levo. I.V.+Ampr) orally at a dose rate of $240 \mathrm{ppm}$. and /or pretreated with toltrazuril (Levo. I.V.+Tolt.) orally at a dose rate of $25 \mathrm{ppm}$.

\begin{tabular}{|c|c|c|c|c|}
\hline Parameter & Unit & \multicolumn{3}{|c|}{ Mean \pm S.E. } \\
\hline & & Levofloxacin & Levofloxacin + Amprolium & Levofloxacin + Toltrazuril \\
\hline $\mathrm{Cp}^{\mathrm{o}}$ & $\mu \mathrm{g} \cdot \mathrm{ml}^{-1}$ & $9.54 \pm 0.52$ & $8.86 \pm 0.38$ & $10.99 \pm 0.23 *$ \\
\hline $\mathrm{A}$ & $\mu \mathrm{g} . \mathrm{ml}^{-1}$ & $5.83 \pm 0.31$ & $6.61 \pm 0.27$ & $5.70 \pm 0.68$ \\
\hline$\alpha$ & $\mathrm{h}^{-1}$ & $4.07 \pm 1.04$ & $3.05 \pm 0.039$ & $3.70 \pm 0.83$ \\
\hline $\mathrm{T}_{0.5(\alpha)}$ & $\mathrm{h}$ & $0.22 \pm 0.032$ & $0.25 \pm 0.04$ & $0.31 \pm 0.094$ \\
\hline $\mathrm{B}$ & $\mu \mathrm{g} . \mathrm{ml}^{-1}$ & $3.72 \pm 0.30$ & $2.58 \pm 0.27^{*}$ & $5.27 \pm 0.85$ \\
\hline$\beta$ & $\mathrm{h}^{-1}$ & $0.18 \pm 0.009$ & $0.183 \pm 0.008$ & $0.17 \pm 0.017$ \\
\hline $\mathrm{T}_{0.5(\beta)}$ & $\mathrm{h}$ & $4.07 \pm 0.24$ & $3.89 \pm 0.24$ & $4.10 \pm 0.45$ \\
\hline $\mathrm{AUC}_{(0 \text {-inf) }}$ & $\mu \mathrm{g} \cdot \mathrm{h} \cdot \mathrm{ml}^{-1}$ & $23.05 \pm 0.47$ & $16.31 \pm 0.70 * * *$ & $31.99 \pm 1.44 * * *$ \\
\hline MRT & $\mathrm{h}$ & $5.40 \pm 0.26$ & $4.77 \pm 0.28$ & $5.38 \pm 0.36$ \\
\hline $\mathrm{K}_{12}$ & $\mathrm{~h}^{-1}$ & $2.11 \pm 0.43$ & $1.67 \pm 0.24$ & $1.40 \pm 0.35$ \\
\hline $\mathrm{K}_{21}$ & $\mathrm{~h}^{-1}$ & $1.74 \pm 0.49$ & $1.02 \pm 0.18$ & $2.13 \pm 0.55$ \\
\hline $\mathrm{K}_{\mathrm{el}}$ & $\mathrm{h}^{-1}$ & $0.41 \pm 0.019$ & $0.57 \pm 0.031 * *$ & $0.35 \pm 0.013^{*}$ \\
\hline $\mathrm{Vc}$ & $\mathrm{L} / \mathrm{Kg}$ & $1.07 \pm 0.05$ & $1.14 \pm 0.052$ & $0.91 \pm 0.019^{*}$ \\
\hline $\mathrm{Vd}_{\text {area }}$ & $\mathrm{L} / \mathrm{Kg}$ & $2.52 \pm 0.15$ & $3.46 \pm 0.27^{*}$ & $1.90 \pm 0.27$ \\
\hline $\mathrm{Vd}_{\mathrm{sS}}$ & $\mathrm{L} / \mathrm{Kg}$ & $2.36 \pm 0.13$ & $3.05 \pm 0.17 *$ & $1.71 \pm 0.17^{*}$ \\
\hline $\mathrm{Vd}_{\beta}$ & $\mathrm{L} / \mathrm{kg}$ & $2.51 \pm 0.51$ & $3.62 \pm 0.23 * *$ & $1.91 \pm 0.28^{*}$ \\
\hline $\mathrm{CL}_{\text {tot }}$ & $\mathrm{L} / \mathrm{kg} / \mathrm{h}$ & $0.44 \pm 0.009$ & $0.65 \pm 0.023 * * *$ & $0.32 \pm 0.015 * * *$ \\
\hline
\end{tabular}




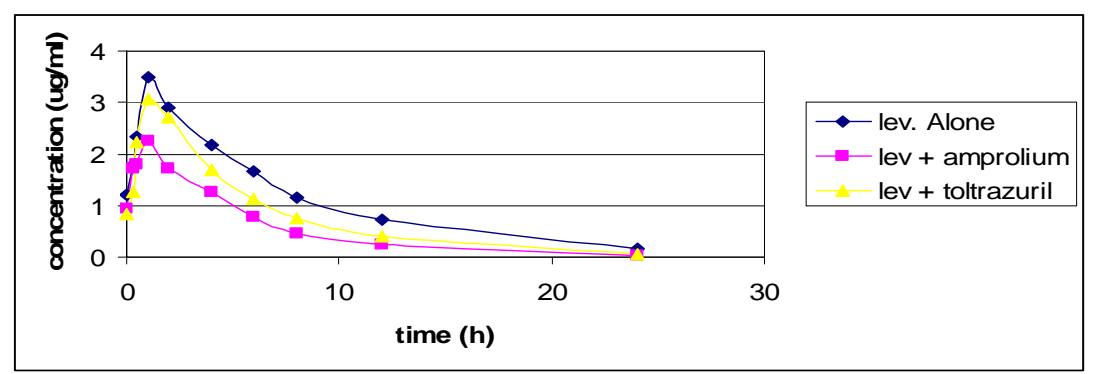

Fig. 2: Graph depicting the time course of levofloxacin in serum of broilers after a single oral administration of $10 \mathrm{mg} / \mathrm{kg} . b . w t$. alone, pretreated with amprolium and pretreated with toltrazuril.

Table 2: Mean pharmacokinetic parameters of levofloxacin in broilers after a single oral administration of $10 \mathrm{mg} / \mathrm{kg}$. b.wt. alone (Levo.P.O.) and /or pretreated with amprolium (Levo. P.O.+Ampr) orally at a dose rate of $240 \mathrm{ppm}$. and /or pretreated with toltrazuril (Levo.P.O.+Tolt.) orally at a dose rate of $25 \mathrm{ppm}$.

\begin{tabular}{|c|c|c|c|c|}
\hline Parameter & Unit & \multicolumn{3}{|c|}{ Mean \pm S.E. } \\
\hline & & Levofloxacin & Levofloxacin + Amprolium & Levofloxacin + Toltrazuril \\
\hline $\mathrm{A}$ & $\mu \mathrm{g} \cdot \mathrm{ml}^{-1}$ & $4.38 \pm 0.27$ & $2.63 \pm 0.26 * * *$ & $4.50 \pm 0.28$ \\
\hline $\mathrm{K}_{\mathrm{ab}}$ & $\mathrm{h}^{-1}$ & $2.26 \pm 0.23$ & $3.45 \pm 0.52 *$ & $2.02 \pm 0.11$ \\
\hline $\mathrm{T}_{0.5(\mathrm{ab})}$ & $\mathrm{h}$ & $0.32 \pm 0.03$ & $0.22 \pm 0.023^{*}$ & $0.35 \pm 0.02$ \\
\hline $\mathrm{B}$ & $\mu \mathrm{g} \cdot \mathrm{ml}^{-1}$ & $4.39 \pm 0.27$ & $2.81 \pm 0.18 * * *$ & $4.50 \pm 0.28$ \\
\hline $\mathrm{K}_{\mathrm{el}}$ & $h^{-1}$ & $0.17 \pm 0.01$ & $0.22 \pm 0.008^{*}$ & $0.24 \pm 0.008 * *$ \\
\hline $\mathrm{T}_{0.5(\mathrm{el})}$ & $\mathrm{h}$ & $4.24 \pm 0.28$ & $3.22 \pm 0.13 * *$ & $2.98 \pm 0.11 * *$ \\
\hline $\mathrm{C}_{\max }$ & $\mu \mathrm{g} . \mathrm{ml}^{-1}$ & $3.27 \pm 0.13$ & $2.17 \pm 0.097 * * *$ & $2.95 \pm 0.11$ \\
\hline $\mathrm{T}_{\max }$ & $\mathrm{h}$ & $1.32 \pm 0.096$ & $0.92 \pm 0.057 * *$ & $1.30 \pm 0.037$ \\
\hline $\mathrm{AUC}_{(0-\text {-inf })}$ & $\mu \mathrm{g} \cdot \mathrm{h} \cdot \mathrm{ml}^{-1}$ & $24.62 \pm 1.78$ & $12.16 \pm 0.31 * * *$ & $16.97 \pm 0.44 * *$ \\
\hline MRT & $\mathrm{h}$ & $6.59 \pm 0.44$ & $4.93 \pm 0.16^{* *}$ & $4.82 \pm 0.13 * *$ \\
\hline IBD & $\mathrm{h}$ & $27.39 \pm 1.80$ & $19.10 \pm 0.58 * *$ & $19.29 \pm 0.51 * *$ \\
\hline $\mathrm{F}$ & $\%$ & $107.47 \pm 9.23$ & $75.74 \pm 4.50$ & $53.51 \pm 2.45$ \\
\hline
\end{tabular}

Table 3: Mean serum and tissues concentrations of levofloxacin ( $\mu \mathrm{g} / \mathrm{ml}$ or $\mu \mathrm{g} / \mathrm{gm})$ assayed microbiologically, in control and amprolium pretreated broiler chickens following oral administration of $10 \mathrm{mg} / \mathrm{kg}$.b. wt. once daily for 3 consecutive days. $\mathrm{n}=3$.

\begin{tabular}{|c|c|c|c|c|c|c|c|c|c|c|c|c|}
\hline \multirow[t]{4}{*}{ Tissue } & \multicolumn{12}{|c|}{ Mean \pm S.E. } \\
\hline & \multicolumn{12}{|c|}{ Time of slaughter after the last dose } \\
\hline & \multicolumn{6}{|c|}{ Levofloxacin } & \multicolumn{6}{|c|}{ Levofloxacin + Amprolium } \\
\hline & $2 \mathrm{~h}$ & $1^{\text {st }}$ day & $3^{\text {rd }}$ day & $5^{\text {th }}$ day & $7^{\text {th }}$ day & $9^{\text {th }}$ day & $2 \mathrm{~h}$ & $1^{\text {st }}$ day & $3^{\text {rd }}$ day & $5^{\text {th }}$ day & $7^{\text {th }}$ day & $9^{\text {th }}$ day \\
\hline Serum & $\begin{array}{c}2.80 \pm \\
0.17\end{array}$ & $\begin{array}{c}0.22 \pm \\
0.01\end{array}$ & $\begin{array}{c}0.76 \pm \\
0.05\end{array}$ & $\begin{array}{c}1.23 \pm \\
0.01\end{array}$ & $\begin{array}{c}0.98 \pm \\
0.01\end{array}$ & - & $\begin{array}{c}1.80 \pm \\
0.12\end{array}$ & $\begin{array}{c}0.095 \pm \\
0.002\end{array}$ & $\begin{array}{c}1.83 \pm \\
0.02\end{array}$ & $\begin{array}{c}0.39 \pm \\
0.04\end{array}$ & $\begin{array}{c}0.23 \pm \\
0.01\end{array}$ & - \\
\hline Liver & $\begin{array}{c}8.30 \pm \\
1.70\end{array}$ & $\begin{array}{c}1.39 \pm \\
0.19\end{array}$ & $\begin{array}{c}1.63 \pm \\
0.13\end{array}$ & $\begin{array}{c}0.65 \pm \\
0.05\end{array}$ & $\begin{array}{c}0.096 \pm \\
0.003\end{array}$ & $\begin{array}{c}0.035 \pm \\
0.003\end{array}$ & $\begin{array}{c}2.37 \pm \\
0.31\end{array}$ & $\begin{array}{c}2.53 \pm \\
0.22\end{array}$ & $\begin{array}{c}0.65 \pm \\
0.04\end{array}$ & $\begin{array}{c}0.22 \pm \\
0.01\end{array}$ & $\begin{array}{c}0.03 \pm \\
0.003\end{array}$ & - \\
\hline Spleen & $\begin{array}{c}3.70 \pm \\
0.30\end{array}$ & $\begin{array}{c}0.63 \pm \\
0.02\end{array}$ & $\begin{array}{c}0.22 \pm \\
0.05\end{array}$ & $\begin{array}{c}0.16 \pm \\
0.01\end{array}$ & $\begin{array}{c}0.06 \pm \\
0.003\end{array}$ & - & $\begin{array}{c}1.97 \pm \\
0.19\end{array}$ & $\begin{array}{c}0.20 \pm \\
0.01\end{array}$ & $\begin{array}{c}0.07 \pm \\
0.003\end{array}$ & $\begin{array}{c}0.05 \pm \\
0.002\end{array}$ & $\begin{array}{c}0.03 \pm \\
0.001\end{array}$ & - \\
\hline Kidney & $\begin{array}{c}9.33 \pm \\
0.16 \\
\end{array}$ & $\begin{array}{c}2.47 \pm \\
0.23\end{array}$ & $\begin{array}{c}1.73 \pm \\
0.07\end{array}$ & $\begin{array}{c}1.05 \pm \\
0.03\end{array}$ & $\begin{array}{c}0.20 \pm \\
0.01\end{array}$ & $\begin{array}{c}0.07 \pm \\
0.001 \\
\end{array}$ & $\begin{array}{c}2.70 \pm \\
0.24\end{array}$ & $\begin{array}{c}0.61 \pm \\
0.02 \\
\end{array}$ & $\begin{array}{c}0.19 \pm \\
0.01\end{array}$ & $\begin{array}{c}0.16 \pm \\
0.01 \\
\end{array}$ & $\begin{array}{c}0.11 \pm \\
0.01 \\
\end{array}$ & $\begin{array}{c}0.06 \pm \\
0.003\end{array}$ \\
\hline Lung & $\begin{array}{c}1.73 \pm \\
0.13\end{array}$ & $\begin{array}{c}0.64 \pm \\
0.04\end{array}$ & $\begin{array}{c}0.46 \pm \\
0.01\end{array}$ & $\begin{array}{c}0.05 \pm \\
0.003\end{array}$ & - & - & $\begin{array}{c}1.09 \pm \\
0.07\end{array}$ & $\begin{array}{c}0.47 \pm \\
0.01\end{array}$ & $\begin{array}{c}0.57 \pm \\
0.03\end{array}$ & $\begin{array}{c}0.034 \pm \\
0.003\end{array}$ & - & - \\
\hline Fat & $\begin{array}{c}1.33 \pm \\
0.12\end{array}$ & $\begin{array}{c}0.69 \pm \\
0.05\end{array}$ & $\begin{array}{c}0.35 \pm \\
0.03\end{array}$ & $\begin{array}{c}0.21 \pm \\
0.02\end{array}$ & $\begin{array}{c}0.05 \pm \\
0.001\end{array}$ & - & $\begin{array}{c}1.19 \pm \\
0.05\end{array}$ & $\begin{array}{c}0.93 \pm \\
0.11\end{array}$ & $\begin{array}{c}0.30 \pm \\
0.02\end{array}$ & $\begin{array}{c}0.04 \pm \\
0.001\end{array}$ & - & - \\
\hline Breast ms & $\begin{array}{c}2.73 \pm \\
0.17\end{array}$ & $\begin{array}{c}0.23 \pm \\
0.04\end{array}$ & $\begin{array}{c}0.17 \pm \\
0.01\end{array}$ & $\begin{array}{c}0.05 \pm \\
0.002\end{array}$ & - & - & $\begin{array}{c}3.03 \pm \\
0.28\end{array}$ & $\begin{array}{c}0.25 \pm \\
0.07\end{array}$ & $\begin{array}{c}0.49 \pm \\
0.03\end{array}$ & $\begin{array}{c}0.04 \pm \\
0.002\end{array}$ & - & - \\
\hline
\end{tabular}


Table 4: Mean serum and tissues concentrations of levofloxacin $(\mu \mathrm{g} / \mathrm{ml}$ or $\mu \mathrm{g} / \mathrm{gm})$ assayed microbiologically, in control and toltrazuril pretreated broiler chickens following oral administration of $10 \mathrm{mg} / \mathrm{kg}$.b. wt. once daily for 3 consecutive days. $\mathrm{n}=3$.

\begin{tabular}{|c|c|c|c|c|c|c|c|c|c|c|c|c|}
\hline \multirow[t]{4}{*}{ Tissue } & \multicolumn{12}{|c|}{ Mean \pm S.E. } \\
\hline & \multicolumn{12}{|c|}{ Time of slaughter after the last dose } \\
\hline & \multicolumn{6}{|c|}{ Levofloxacin } & \multicolumn{6}{|c|}{ Levofloxacin + Toltrazuril } \\
\hline & $2 \mathrm{~h}$ & $1^{\text {st }}$ day & $3^{\text {rd }}$ day & $5^{\text {th }}$ day & $7^{\text {th }}$ day & $9^{\text {th }}$ day & $2 \mathrm{~h}$ & $1^{\text {st }}$ day & $3^{\text {rd }}$ day & $5^{\text {th }}$ day & $7^{\text {th }}$ day & $9^{\text {th }}$ day \\
\hline Serum & $\begin{array}{c}2.80 \pm \\
0.17\end{array}$ & $\begin{array}{c}0.22 \pm \\
0.01\end{array}$ & $\begin{array}{c}0.76 \pm \\
0.05\end{array}$ & $\begin{array}{c}1.23 \pm \\
0.01\end{array}$ & $\begin{array}{c}0.98 \pm \\
0.01\end{array}$ & - & $\begin{array}{c}3.10 \pm \\
0.21\end{array}$ & $\begin{array}{c}0.39 \pm \\
0.03\end{array}$ & $\begin{array}{c}0.64 \pm \\
0.03\end{array}$ & $\begin{array}{c}0.98 \pm \\
0.05\end{array}$ & $\begin{array}{c}1.60 \pm \\
0.12\end{array}$ & $\begin{array}{c}0.263 \pm \\
0.02\end{array}$ \\
\hline Liver & $\begin{array}{c}8.30 \pm \\
1.70 \\
\end{array}$ & $\begin{array}{c}1.39 \pm \\
0.19\end{array}$ & $\begin{array}{c}1.63 \pm \\
0.13\end{array}$ & $\begin{array}{c}0.65 \pm \\
0.05\end{array}$ & $\begin{array}{c}0.096 \pm \\
0.003\end{array}$ & $\begin{array}{c}0.035 \pm \\
0.003\end{array}$ & $\begin{array}{c}8.80 \pm \\
1.20 \\
\end{array}$ & $\begin{array}{c}4.33 \pm \\
0.33\end{array}$ & $\begin{array}{c}2.33 \pm \\
0.17 \\
\end{array}$ & $\begin{array}{c}1.13 \pm \\
0.07 \\
\end{array}$ & $\begin{array}{c}0.40 \pm \\
0.01 \\
\end{array}$ & $\begin{array}{c}0.10 \pm \\
0.002 \\
\end{array}$ \\
\hline Spleen & $\begin{array}{c}3.70 \pm \\
0.30\end{array}$ & $\begin{array}{c}0.63 \pm \\
0.02\end{array}$ & $\begin{array}{c}0.22 \pm \\
0.05\end{array}$ & $\begin{array}{c}0.16 \pm \\
0.01\end{array}$ & $\begin{array}{l}0.06 \pm \\
0.003\end{array}$ & - & $\begin{array}{c}6.67 \pm \\
0.27\end{array}$ & $\begin{array}{c}3.03 \pm \\
0.28\end{array}$ & $\begin{array}{c}1.87 \pm \\
0.11\end{array}$ & $\begin{array}{c}1.02 \pm \\
0.04\end{array}$ & $\begin{array}{c}0.33 \pm \\
0.02\end{array}$ & $\begin{array}{c}0.053 \pm \\
0.001\end{array}$ \\
\hline Kidney & $\begin{array}{c}9.33 \pm \\
0.16 \\
\end{array}$ & $\begin{array}{c}2.47 \pm \\
0.23\end{array}$ & $\begin{array}{c}1.73 \pm \\
0.07\end{array}$ & $\begin{array}{c}1.05 \pm \\
0.03\end{array}$ & $\begin{array}{c}0.20 \pm \\
0.01\end{array}$ & $\begin{array}{c}0.07 \pm \\
0.001 \\
\end{array}$ & $\begin{array}{c}9.33 \pm \\
0.67 \\
\end{array}$ & $\begin{array}{c}6.67 \pm \\
0.71 \\
\end{array}$ & $\begin{array}{c}3.73 \pm \\
0.33 \\
\end{array}$ & $\begin{array}{c}1.73 \pm \\
0.13 \\
\end{array}$ & $\begin{array}{c}1.05 \pm \\
0.073 \\
\end{array}$ & $\begin{array}{c}0.16 \pm \\
0.004 \\
\end{array}$ \\
\hline Lung & $\begin{array}{c}1.73 \pm \\
0.13 \\
\end{array}$ & $\begin{array}{c}0.64 \pm \\
0.04 \\
\end{array}$ & $\begin{array}{c}0.46 \pm \\
0.01 \\
\end{array}$ & $\begin{array}{c}0.05 \pm \\
0.003\end{array}$ & - & - & $\begin{array}{c}2.23 \pm \\
0.15 \\
\end{array}$ & $\begin{array}{c}0.86 \pm \\
0.07\end{array}$ & $\begin{array}{l}0.61 \pm \\
0.004 \\
\end{array}$ & $\begin{array}{c}0.096 \pm \\
0.006 \\
\end{array}$ & $\begin{array}{c}0.04 \pm \\
0.001 \\
\end{array}$ & - \\
\hline Fat & $\begin{array}{c}1.33 \pm \\
0.12 \\
\end{array}$ & $\begin{array}{c}0.69 \pm \\
0.05\end{array}$ & $\begin{array}{c}0.35 \pm \\
0.03\end{array}$ & $\begin{array}{c}0.21 \pm \\
0.02\end{array}$ & $\begin{array}{c}0.05 \pm \\
0.001\end{array}$ & - & $\begin{array}{c}1.87 \pm \\
0.13 \\
\end{array}$ & $\begin{array}{c}1.01 \pm \\
0.02\end{array}$ & $\begin{array}{c}0.61 \pm \\
0.008\end{array}$ & $\begin{array}{c}0.28 \pm \\
0.023 \\
\end{array}$ & $\begin{array}{c}0.053 \pm \\
0.001\end{array}$ & - \\
\hline Breast ms & $\begin{array}{c}2.73 \pm \\
0.17 \\
\end{array}$ & $\begin{array}{c}0.23 \pm \\
0.04\end{array}$ & $\begin{array}{c}0.17 \pm \\
0.01\end{array}$ & $\begin{array}{c}0.05 \pm \\
0.002\end{array}$ & - & - & $\begin{array}{c}2.90 \pm \\
0.20 \\
\end{array}$ & $\begin{array}{c}0.98 \pm \\
0.11\end{array}$ & $\begin{array}{l}0.24 \pm \\
0.007\end{array}$ & $\begin{array}{c}0.05 \pm \\
0.003\end{array}$ & - & - \\
\hline
\end{tabular}

\section{DISCUSSION}

After IV injection of levofloxacin alone, pretreated with amprolium and pretreated with toltrazuril in broiler chickens, the drug serum concentration-time curve was best to be described by a two-compartment open model. This is in agreement with Varia et al. (2009) in broiler chickens, Goudah and Abo El-Sooud (2009) in lactating goats and Goudah et al. (2008) in stallion. The obtained results showed that a significant decrease in the serum levofloxacin concentration in broiler pretreated with amprolium following the IV administration of the drug at different time intervals. On the other hand, birds pretreated with toltrazuril exhibit a significant increase in serum level of levofloxacin following its IV injection. The elimination half-life of the drug in control broiler chickens was $4.07 \mathrm{~h}$. This result is nearly similar to that reported in broiler chickens (3.18 h.; Varia et al., 2009) and for other fluoroquinolones as ofloxacin in chickens (4.44 h.; Kalaiselvi et al., 2006) and pefloxacin in broilers (3.25 h.; Dimitrova et al., 2008). The elimination half-life was longer to that reported in lactating goats (2.95 h.; Goudah and Abo El-Sooud, 2009), however it was shorter than elimination half-life of danofloxacin $(6.73 \mathrm{~h})$ reported in chickens (Knoll et al., 1999). Thus, levofloxacin is more rapidly eliminated than other fluoroquinolones in broiler chickens. The elimination half-life of levofloxacin following intravenous injection in chickens pretreated with either amprolium or toltrazuril was 3.89 and $4.10 \mathrm{~h}$ respectively. Total body clearance of the drug in the present study $(0.44 \mathrm{~L} / \mathrm{kg} / \mathrm{h}$.) was higher than values determined previously in coloured broiler chickens $(0.24 \mathrm{~L} / \mathrm{kg} / \mathrm{h}$.; Varia et al., 2009$)$ and in lactating goats $(0.18 \mathrm{~L} / \mathrm{kg} / \mathrm{h}$.; Goudah and Abo El-Sooud, 2009). This value $(0.44 \mathrm{~L} / \mathrm{kg} / \mathrm{h}$.) is significantly lower than that recorded in birds pre-treated with amprolium $(0.65 \mathrm{~L} / \mathrm{kg} / \mathrm{h}$.) but significantly higher than broilers pretreated with toltrazuril $(0.32 \mathrm{~L} / \mathrm{kg} / \mathrm{h}$.). In the current study, however, the $\mathrm{Vd}_{\mathrm{ss}}$ for levofloxacin in broilers was found to be $2.36 \mathrm{~L} / \mathrm{kg}$ ) which was significantly lower than values determined in broilers pretreated with amprolium (3.05 $\mathrm{L} / \mathrm{kg}$ ) and significantly higher than values determined for levofloxacin in broiler chickens pretreated with toltrazuril $(1.71 \mathrm{~L} / \mathrm{kg})$. These findings were consistent with and explained the lower serum concentration and wide distribution of levofloxacin in 
birds pretreated with amprolium and the higher serum concentration of the drug in broilers pre-treated with toltrazuril. However, these values were much higher than $\mathrm{Vd}_{\mathrm{ss}}$ reported for levofloxacin in stallion (Goudah et al., 2008). Such differences are relatively common and are frequently related to inter-species variation, assay methods used, the amount of time between blood samplings, and/or the health status and age of the animal (Haddad et al., 1985). The present study showed that levofloxacin was rapidly transferred from the peripheral compartment to central one in control and pretreated with amprolium than from the central compartment to peripheral ones. Closely similar findings were previously recorded for enrofloxacin in broilers (Parlar and Kaya, 2005).

Following oral administration, the mean serum concentrations of levofloxacin were significantly lower in amprolium and toltrazuril pretreated broilers compared to control broilers. Similar findings were previously reported for amprolium with enrofloxacin in broilers (Rania, 2007). In this respect, Rania reported that, coccidia infected birds pretreated with amprolium exhibit a lower serum enrofloxacin concentration. Furthermore, birds infected with coccidia and pretreated with toltrazuril showed a marked significant decrease in levofloxacin serum concentration.

The calculated values of $\mathrm{C}_{\max }$ and $\mathrm{T}_{\max }$ for healthy broilers $(3.27 \mu \mathrm{g} / \mathrm{ml}$ and 1.32 $\mathrm{h}$ respectively) reported in the present study were consistent with enrofloxacin in broilers $\left(\mathrm{C}_{\max } 2.44 \mu \mathrm{g} / \mathrm{ml}\right.$ and $\mathrm{T}_{\max } 1.64 \mathrm{~h}$.; Anadon et al., 1995). On the other hand, the obtained values were higher than enrofloxacin in broilers $\left(\mathrm{C}_{\max } 1.50 \mu \mathrm{g} / \mathrm{ml}\right.$; Silva et al., 2006) and ( $\mathrm{C}_{\max } 0.99 \mu \mathrm{g} / \mathrm{ml}$.; Bugyei et al., 1999). This difference could be referred to the difference in doses used $(10 \mathrm{mg} / \mathrm{kg}$ in our study and $5 \mathrm{mg} / \mathrm{kg}$ in their studies). The lower calculated $\mathrm{C}_{\max }$ for levofloxacin in birds pretreated with either amprolium $\left(\mathrm{C}_{\max } 2.17 \mu \mathrm{g} / \mathrm{ml}\right)$ or toltrazuril $\left(\mathrm{C}_{\max } 2.95 \mu \mathrm{g} / \mathrm{ml}\right)$ compared with healthy ones $\left(\mathrm{C}_{\max } 3.27 \mu \mathrm{g} / \mathrm{ml}\right)$ was closely consistent with shorter $t_{0.5(\mathrm{el})}$ for levofloxacin in birds pretreated with either amprolium $(3.22 \mathrm{~h})$ or toltrazuril $(2.98 \mathrm{~h})$ compared with healthy ones $(4.24 \mathrm{~h})$. This observation could be attributed to the rapid elimination rate constant coupled with pharmacological interaction previously recorded for salinomycin (El-Barawy, 2000). El-Barawy found that serum concentration of enrofloxacin $\left(\mathrm{C}_{\max }\right)$ was significantly lower in salinomycin treated chickens. On the other hand, the lower $\mathrm{C}_{\max }$ of levofloxacin when pretreated with either amprolium or toltrazuril in broilers could be explained on the basis of the effect of amprolium and toltrazuril on microsomal enzymes of liver. In this respect, similar observation was previously reported by Abo El-Sooud (2003) on co-administration of enrofloxacin with albendazole in goats. Both albendazole and toltrazuril are highly metabolized to sulphone in liver (Brander et al., 1991), a phenomenon which could explain the probable similarity of both drugs in inducing CYP 450 enzymes in animals and birds and consequently the rapid metabolism and lower $\mathrm{C}_{\max }$ of levofloxacin. Pretreatment of chickens with toltrazuril two days before levofloxacin administration is enough time to induce liver microsomal CYP 450 enzymes, although Abo El-Sooud (2003) found that a single dose of albendazole was sufficient to induce such induction in goats. On the other hand, both fluoroquinolone enrofloxacin and norfloxacin were found to inhibit hepatic microsomal cytochrome P-450 monooxygenases in the livers of broiler chickens using dosages as given in commercial flocks. Enrofloxacin is more markedly inhibited hydroxylation of aniline (Shlosberg et al., 1997). Concerning possible interaction between fluroquinolones and anticoccidials, Ershov et al. (2001) found that co-administration of monensin or lasalocid was not shown to alter blood levels of enrofloxacin, but norfloxacin-lasalocid coadministration induced 
aminopyrine N-demethylase (AD) activity and induced rise of norfloxacin levels in blood.

The obtained results showed lower systemic bioavailability of levofloxacin in birds pretreated with either amprolium $(75.74 \%)$ or toltrazuril $(53.51 \%)$ as compared to values in healthy birds $(107.47 \%)$ a logic effect related to impair intestinal absorption of the given drugs. Our value was higher than enrofloxacin in broilers (59.61\%.; Abdel-Aziz et al., 1997) and those recorded for levofloxacin in coloured broilers (59.54.; Varia et al., 2009). On the other hand, this value was similar to ofloxacin (110.01\%) and danofloxacin (99.2\%) reported in chickens (Kalaiselvi et al., 2006; Knoll et al., 1999). Levofloxacin has a low tendency to bind with plasma protein of chickens $(4.21 \pm 0.48 \%)$. This value was lower than the binding of levofloxacin to the plasma proteins of goats $(22 \%)$ reported by Goudah and Abo El Sooud (2009) and 17\% in calves (Dumka and Srivastava, 2006).

The obtained results showed that the drug was distributed in serum, and tested tissues (Liver, spleen, kidney, lung, fat, and breast muscle). Kidney had the highest concentration of levofloxacin followed by liver and spleen, while the lowest concentration was determined in fat and muscle in both control and pretreated birds. Similar findings were previously reported for enrofloxacin in broiler chickens (AbdelAziz et al., 1997; Knoll et al., 1999; Al-Khayyat et al., 2000; Soliman, 2000). Oral administration of levofloxacin once daily for 3 consecutive days in toltrazuril pretreated chickens resulted in a higher tissues concentration of the drug at different time interval after stopping dosage regimen as compared with values recorded in control birds. On the other hand, lower tissues concentration of the drug at different time interval after stopping dosage regimen in amprolium pretreated as compared with values recorded in control birds which could be attributed to the inducing effect of amprolium on liver microsomal enzymes. Similar observation was previously reported by Abo El-Sooud (2003). Pretreatment of chickens with amprolium for five days before levofloxacin administration is enough time for induction of liver microsomal CYP 450 enzymes, although Abo El-Sooud (2003) found that a single dose of albendazole was sufficient to induce such effect in goats. High levofloxacin concentrations in different organs indicate its excellence for treating urinary and respiratory tract infections caused by susceptible organisms. Similar results showing high concentrations of moxifloxacin in different tissues of chickens were reported by Goudah (2009).

Using the microbiological assay technique, levofloxacin was still detected in serum, and some tested tissues on the $9^{\text {th }}$ day after discontinuation of medication in both control and pretreated birds with either amprolium or toltrazuril. These findings mean that the withdrawal period of levofloxacin is more than 9 days in poultry when added to drinking water. Withdrawal time of levofloxacin was extended in toltrazuriltreated and healthy birds, followed by amprolium-treated chickens.

\section{REFERENCES}

Abd El-Aziz, M.I.; Aziza, M.A.; Soliman, F.A. and Afify, N.A. (1997): Pharmacokinetic evaluation of enrofloxacin in chickens. British Poultry Science, 38: 164-168.

Abdelsalam, E.B. and Ford, E.J.H. (1986): Effect of pretreatment with hepatic microsomal enzyme inducers on the toxicity of diazinon in calves. Res. Vet. Sci., 41: 336-339. 
Abou El-Sooud, K. (2003): Influence of albendazole on the disposition kinetics and milk antimicrobial equivalent activity of enrofloxacin in lactating goats. Pharmacology Research, 48(4): 389-395.

Al-Khayyat, A.A.; Al-Shaha, O.M.S. and Al-Khafaji, B.A. (2000): Plasma and respiratory tissue levels of three fluroquinolones in layer chickens. Iraqi Journal of Veterinary Science, 13(1):1-16.

Anadon, A.; Martinez-Lannanaga, M.R.; Diaz, M.J.; Bringas, P.; Martinez, M.A.; Fernandez-Cruz, M.L.; Fernandez, M.C. and Fernandez, R. (1995): Pharmacokinetics and residues of enrofloxacin in chicken. Am. J. Vet. Res., 56: 501-506.

Arret, B.; Johnson, D.P. and Kirshboum, A. (1971): Out line of details for microbiological assay of antibiotics, second revision. Pharmacology Science, 60(11): 1689-1694.

Baggot, J.D. (1978): Some aspects of clinical pharmacokinetics in veterinary medicine. J. Vet. Pharmacol. Ther., 1: 5-7.

Brander, G.C.; Pugh, D.M.; Baywater, R.J. and Jenkins, W.L. (1991): Veterinary Applied Pharmacology and Therapeutics. Fifth Ed. The English language Book Society and Boilliere, Trindall, London.

Bugyei, K.; Black, W.D. and Mc-Ewen, S. (1999): Pharmacokinetics of enrofloxacin given by the oral, intravenous and intramuscular routes in broiler chickens. Canad. J. Vet. Res., 63(3): 193-200.

Dimitrova, D.; Moutafchieva, R.; Kanelov, I.; Dinev, T.; Yanev, S.; Pandova, B. and Lasev, L. (2008): Pharmacokinetics of pefloxacin and its metabolite norfloxacin in male and female broilers. J. Vet. Pharmacol. Ther., 31: 167-70.

Dumka, V.K. and Srivastava, A.K. (2006): Pharmacokinetics, urinary excretion and dosage regimen of levofloxacin following a single intramuscular administration in cross bred calves. J. Vet. Sci., 7(4): 333-337.

Echman, M.K. (1997): Anticoccidials feed additive programmes. International Poultry Production., 5: 7-9.

El-Barawy, A.M.A. (2000): Effect of the anticoccidial drug salinomycin on disposition kinetics tissue residues of amoxicillin and enrofloxacin in chickens. Ph.D. Thesis presented to Faculty of Veterinary Medicine, Cairo University

Ershov E.; Bellaiche, M.; Hanji, V.; Sobak, S.; Gips, M. and Shlosberg, A. (2001): Interaction of fluroquinolones and certain ionophores in broilers: Effect on certain blood levels and hepatic cytochrome P-450 monooxygenase activity. Drug Metabolism and Drug Interactions, 18(3-4): 209-219.

Goudah, A. (2009): Pharmacokinetics and tissue residues of moxifloxacin in broiler chickens. British Poultry Science, 50(20): 251-258.

Goudah, A. and Abo-El-Sooud, K. (2009): Pharmacokinetics, urinary excretion and milk penetration of levofloxacin in lactating goats J. Vet. Pharmacol. Ther., 32(1): 101-104.

Goudah, A.; Abo-El-Sooud, K.; Shin, H.C.; Shim, J.H. and Abd El-Aty, A.M. (2008): Characterization of the pharmacokinetic disposition of levofloxacin in stallions after intravenous and intramuscular administration. J. Vet. Phamacol. Ther., 31(5): 399-405.

Haddad, N.S.; Pedersol, J.P.; Ravis, W.R.; Fazel, M.H. and Carson, R.L. (1985): Pharmacokinetics of gentamicin at steady-state in ponies, serum, urine and endometrial concentration. Am. J. Vet. Res., 46(6): 1268-1271.

Jones, F.T. and Ricke, S.C. (2003): Observations on the history of the development of antimicrobials and their use in poultry feeds. Poultry Science., 82(4): 613-617. 
Kalaiselvi, L.; Sriranjani, D.; Ramesh, S.; Sriram, P. and Mathuram, L.N. (2006): Pharmacokinetics of ofloxacin in broiler chicken. J. Vet. Pharmacol. Ther., 29: $185-189$.

Knoll, U.; Glunder, G. and Kietzmann, M. (1999): Comparative study of plasma pharmacokinetics and tissue concentration of danofloxacin and levofloxacin in broiler chickens. J.Vet. Pharmacol. Ther., 22: 239-246.

Lorian, V. (1975): Antibiotics in laboratory medicine. USA, $3^{\text {rd }}$ ed., Wilking Baltimore, London, pp. 265-297.

Martinez, M.; McDermott, P. and Walker, R. (2006): Pharmacology of the fluoroquinolones: a perspective for the use in domestic animals. Vet. J., 172(1): $10-28$.

McDougald, L.R. and Reid, W.M. (1997): Coccidiosis. In: B.W. Calnek (Eds). Diseases of poultry. $10^{\text {th }}$ Ed. (Iowa State University Press, Ames). Pp. 865-883.

North, D.S.; Fish, D.N. and Redington, J.J. (1998): Levofloxacin, a second-generation fluoroquinolone. Pharmacotherapy, 18: 915-935.

Parlar, A. and Kaya, S. (2005): The pharmacokinetics of approved medicines including enrofloxacin in broiler. Ankara-Universitesi-Veteriner Facultesi Dergisi 52(2): 99-103.

Rania, H.E. (2007): Pharmacokinetics of some fluoroquinolones in healthy and coccidia infected chickens. Ph.D. Thesis presented to Faculty of Veterinary Medicine, Cairo University.

Shlosberg, A.; Ershov, E.; Bellaiche, M.; Hanji, V.; Weisman, Y. and Soback, S. (1997): The inhibitory effects of the fluoroquinolone antimucrobials norfloxacin and enrofloxacin on hepatic microsomal cytochrome P-450 monooxygenases in broiler chickens. Drug Met. and drug Inter., 14(2): 109-122.

Silva, R.G.; Reyes, F.G.R.; Sartori, J.R. and Rath, S. (2006): Enrofloxacin assay validation and pharmacokinetics following a single oral dose in chickens. Journal of veterinary pharmacology and therapeutics, 29: 365-372.

Snedecor, G.W. and Cokran, W.G. (1980): Statistical Methods. $7^{\text {th }}$ ed. The Iowa State University Press, Ames, Iowa, USA.

Soliman, G.A (2000): Tissue distribution and disposition kinetics of enrofloxacin in healthy and E.coli infected broilers. Dtsch. Tierarztl. Wochenschr., 107(1): 2327.

Varia, D.; Patel, H.; Patel, U.D.; Bhavsar, K. and Thaker, M. (2009): Disposition of levofloxacin following oral administration in broiler chickens. I. J. V. M., 64(4): 118-125.

Vertommen, M. H.; Peek, H. W. and Laan, A. (1990): Efficacy of toltrazuril in broilers and development of a laboratory model for sensitivity testing of Eimeria field isolates. Veterinary Quarterly, 12: 183-192. 


\section{ARABIC SUMMARY}

تأثير الأمبروليم والتولترازوريل على المسار الحركى لعقار الليفوفلوكساسين فى الدواجن

حسنى عوض البنا1 ـ محمد حمدى الحويطى 2 ـ أميرة عبداللطيف2

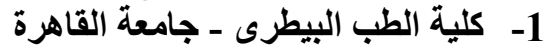
2- كلية الطب البيطرى - جامعة مدينة السادات

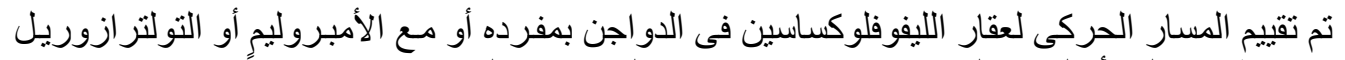

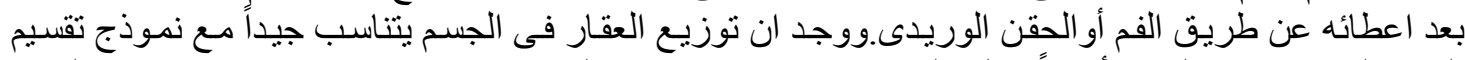

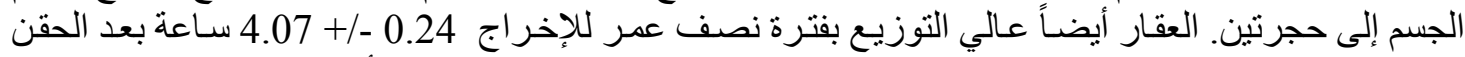

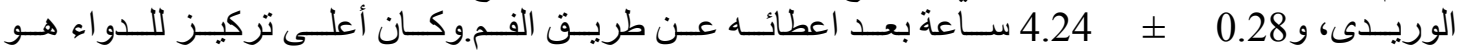

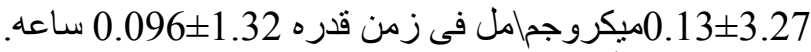

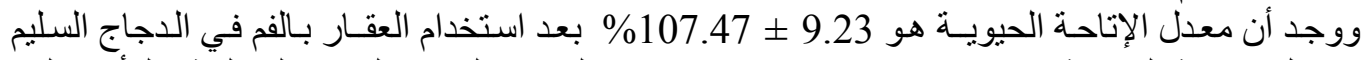

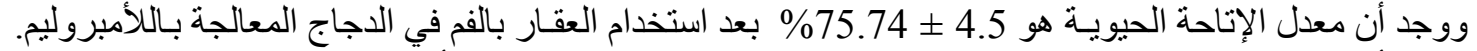

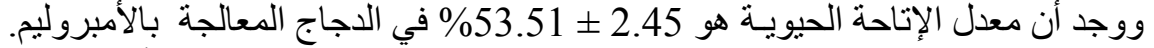

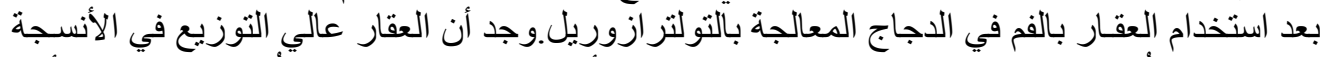

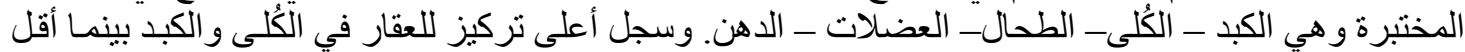

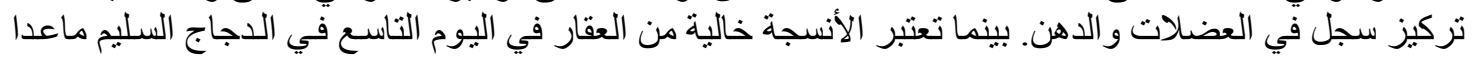
الكبد و الكلى فلايز ال العقار موجود. 